\begin{tabular}{|c|c|c|}
\hline \multirow{3}{*}{$\begin{array}{l}\text { EREM 76/3 } \\
\text { Journal of Environmental Research, } \\
\text { Engineering and Management } \\
\text { Vol. } 76 \text { / No. } 3 \text { / } 2020 \\
\text { pp. 24-34 } \\
\text { DOl 10.5755/j01.erem.76.3.24785 }\end{array}$} & \multicolumn{2}{|c|}{$\begin{array}{c}\text { Using Lime (Citrus } \times \text { aurantiifolia), Orange (Citrus } \times \text { sinensis), } \\
\text { and Tangerine (Citrus reticulata) Waste as a Substrate for } \\
\text { Generating Bioelectricity }\end{array}$} \\
\hline & Received 2020/03 & Accepted after revision 2020/08 \\
\hline & \multicolumn{2}{|c|}{ crossef http://dx.doi.org/10.5755/j01.erem.76.3.24785 } \\
\hline
\end{tabular}

\title{
Using Lime (Citrus $\times$ aurantiifolia), Orange (Citrus $\times$ sinensis), and Tangerine (Citrus reticulata) Waste as a Substrate for Generating Bioelectricity
}

\section{Rojas-Flores, S. *}

Grupo de Investigación en Ciencias Aplicadas y Nuevas Tecnologías, Universidad Privada del Norte, Trujillo 13007, Peru

\section{De La Cruz-Noriega M., Cabanillas-Chirinos L., Santiago M. Benites}

Instituto de Investigación en Ciencias y Tecnología de la Universidad Cesar Vallejo, Trujillo 13001, Peru

\section{Silva-Palacios F., Altamirano-León Rosa, Altamirano-León Zoilita}

Escuela de Ingeneria Ambiental, Facultad de Ingeneria, Universidad Cesar Vallejo, Trujillo 13001, Peru

\section{Angelats-Silva Luis}

Laboratorio de Investigación Multidisciplinaria (LABINM), Universidad Privada Antenor Orrego, Trujillo 13008, Peru

*Corresponding author: segundo.rojas.89@gmail.com

This paper focuses on using lime, orange, and tangerine waste as fuel for the generation of bioelectricity. The tangerine microbial fuel cell evidenced a maximum voltage peak of $1.1 \mathrm{~V}$ on day 13 , while displaying abrupt voltage losses on the following days and throughout the remaining period of substrate monitoring. On the other hand, orange-based fuel denotes lower current generation during these 28 days with values close to $1.6 \mathrm{~mA}$ and $0.25 \mathrm{~mA}$ on the first and last day, respectively. Still, orange generated $3.5 \mathrm{~mA}$ on the first day with values sharply declining in the following days until reaching $0.91 \mathrm{~mA}$ on the last day. In general, substrate volumes in the microbial fuel cells diminished over time, which is consistent with the voltage and current values reported. 
In addition, $\mathrm{pH}$ values increased from day 1 for all substrates, reaching acidic $\mathrm{pH}$ values on the last day of measurement due to the consumption of carbon sources. Tangerine reported the highest current density (CD) at 72 $\mathrm{mW} / \mathrm{cm}^{2}$ and a maximum voltage of 1.06 volts, while orange generated a $C D$ of $62.5 \mathrm{~mW} / \mathrm{cm}^{2}$ and 0.94 volts.

Keywords: microbial fuel cells, voltage, current, acids, organic waste and bioelectricity.

\section{Introduction}

Environmental issues faced by the society due to climate change and excessive consumption of fossil fuels are vigorously degrading our ecosystem (Victor, 2017). As a side consequence, one third of the food production (433.33 million tons) worldwide is wasted annually, which roughly accounts to $\$ 750$ billion (Dahiya et al., 2018). In Peru, wholesale fruit and vegetable markets inefficiently manage their organic waste. In fact, fruit and vegetable waste is usually discarded in surrounding areas, thus causing contamination due to the foul odor and rodents attracted by the fruit and vegetable waste (Centeno et al., 2019). Since their discovery in 1984 (Lefebvre et al., 2010), microbial fuel cells (MFC) have been intensively studied due to the increased interest in using wastewater for the generation of electricity (Shah et al., 2019). MFCs use organic substances as substrates (fuel) by converting chemical energy into electrical energy supported by catalytic reactions involving microorganisms (Rahimnejad et al., 2015). These values of electricity generated by the MFCs can be used in integrated circuits for future simulations with algorithms (Gokul et al., 2020; Gokul et al., 2019).

MFCs are composed of a cathode and an anode, which are commonly separated by a proton exchange membrane (Slate et al., 2019). The electrons ( $\mathrm{e}^{-}$) and protons $\left(\mathrm{p}^{+}\right)$resulting from microbe oxidation in the anode are transferred to the cathode through an external circuit and the membrane itself. These two charges are then consumed, thus reducing the oxidant, which is typically $\mathrm{O}_{2}$ (Gajda et al., 2018; Yu et al., 2018). This type of technology offers a viable solution for leveraging waste, which is usually carelessly discarded by both households and companies. In their work, Li et al. (2016) proved that $120 \mathrm{~mL}$ of food waste can generate 0.5 volts from day 18 to day 30 , for a period of 18 hours until the next fuel supply (Li et al., 2016).
Recently, it has been identified that anthocyanin-rich extracts (such as Vaccinium Spp., C. Terntea Linn, and L. Ruthenicm Murr) used as redox mediators exhibit electrochemical activities, which significantly increase the generation of electricity in MFCs. When comparing C. Terntea Linn and Vaccinium Spp. with L. Ruthenicm Murr, the latter shows the most significant redox mediation capacity and a favorable antioxidant activity due to its higher polyphenol content (anthocyanin) (Xu et al., 2019).

Dual chamber MFCs have also been used as palm tree oil fuel, generating voltage peaks of $0.647 \pm 0.03 \mathrm{~V}$ within the first 80 hours of starting the experiment with a $3.5 \mathrm{~g} / \mathrm{mL}$ sample (Kondaveeti et al., 2019). In the studies conducted by Toding et al. (2018), banana and orange peels were individually used as fuel for a single chamber MFC without chemical pre-treatments or adding mediators, but using copper plates coated with activated carbon powder in the cathode and zinc plates coated with graphite powder in the anode. The experiment results yielded $0.492 \mathrm{~V}$ and $0.101 \mathrm{~mA}$ for the banana peels and $0.563 \mathrm{~V}$ and $0.017 \mathrm{~mA}$ for the orange peels. Grape waste has also been used as fuel in single chamber MFCs using zinc, copper, and magnesium electrodes, as well as thionin and toluidine (red and blue) as mediators. In this case, thionin generated higher voltages peaking at $2.5 \mathrm{~V}$ when using magnesium as electrode, while using toluidine red and blue as mediators generated 2.35 and 2.2 volts, respectively (Sivaa et al., 2014). MFCs have also been designed without requiring proton exchange membranes, using papaya waste as fuel, as well as carbon felt and magnesium oxide as anode and cathode, generating 0.75 to $0.81 \mathrm{~mW} / \mathrm{cm}^{2}$ and a peak voltage of 0.7 volts. The authors concluded that pulp causes variations in cell performance, without causing damage to the electrodes (Khan and Obaid, 2015). 
This research seeks to reuse food waste extracts, such as lime (Citrus $x$ aurantiifolia), orange (Citrus $x$ sinensis), and tangerine (Citrus reticulata) juices in affordable MFCs (without proton exchange membranes). This study focuses on reporting voltage, current, $\mathrm{pH}$, conductivity, current density (CD), and power density (PD) throughout a period of 28 days, thus generating eco-friendly electricity, reducing environmental pollution, and lowering production costs for implantation in the most remote places.

\section{Materials and Methods}

\section{Sample collection and preparation}

Organic lime, orange, and tangerine waste was collected from La Hermelinda Market, Trujillo, Peru. This organic waste was subsequently washed several times with distilled water to remove any impurities (dust, insects, or other pollutants). After washing, the fruits were superficially dried at $22 \pm 2^{\circ} \mathrm{C}$ in a Labtron kiln (LDO-B10) for $24 \mathrm{~h}$. Then, the dried fruit waste was filtered through an extractor (Maqorito-400 rpm), obtaining $250 \mathrm{~mL}$ of waste, before being ultimately transferred to properly sterilized beakers.

\section{Microbial fuel cell production}

Three cells were built for each substrate using $10 \mathrm{~cm}$ acrylic squares serving as fasteners for $16 \times 5 \mathrm{~cm}^{2}$ PVC pipes. In addition, zinc and copper electrodes, each $5 \mathrm{~cm}$ in diameter, for an area of $19.63 \mathrm{~cm}^{2}$, were used, as shown in Fig. 1. A total of 5 holes were made at the top of the electrodes through which they are attached to the upper part of the PVC pipe using copper wire ( $0.3 \mathrm{~mm}$ thick). In addition, a $9-\mathrm{cm}^{2}$ hole was made in the center of the tube to facilitate substrate influx, as well as conductivity and $\mathrm{pH}$ measurements.

Voltages were measured using a multimeter (Prasek Premium PR-85) for 30 minutes per day over a period of 28 days. On the other hand, current was measured through resistors at $10.4( \pm 0.8), 23.5( \pm 0.5)$, $46.4( \pm 0.7), 99.1( \pm 3.1), 197.1( \pm 5.6), 264,387( \pm 6.5)$, $687( \pm 8.7), 808( \pm 8.2)$, and $988( \pm 9.3) \Omega$. Furthermore, to measure $C D$ and $P D$, we used the procedure suggested by Zhuang et al. (2012). Finally, conductivity
Fig. 1. Microbial fuel cell (MFC) prototype

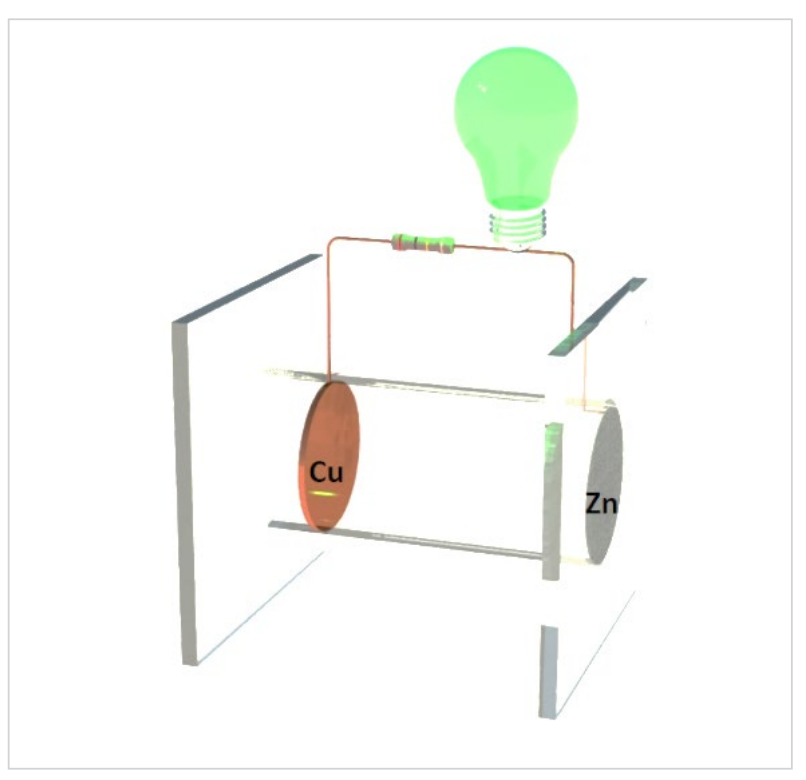

(CD-4301 conductivity meter) and pH (110 Oakton Series $\mathrm{pH}$ meter) changes were also monitored and measured. The microorganisms found in MFCs were identified using a microbiological analyzer, VITEK2 COMPACT (Biomerieux, VK2C-18806, France), and a scanning electron microscope (SEM - TECSAN VEGA 3 LM) equipped with a SPI 11430-AB gold coating system (TESCAN USA) was used for the micrographs. The data points of the voltage, current, and PD and CD figures represent the average values from three replicates and the error bars represent the corresponding standard deviations.

\section{Results and Discussion}

Fig. 2 (a) denotes average voltage $\left(V_{p}\right)$ generation reported by the open MFC circuit for the three types of organic waste. On the first day, tangerine reports the highest $V_{p}$ generation with values of approximately $0.85 \pm 0.02$ volts. However, lime generates a higher $V_{p}$ as of the second day with values exceeding 1 volt until decreasing on the seventh day. Thereafter, these values are surpassed by tangerine until day $23(0.92 \pm 0.01 \mathrm{~V})$, where its $V_{p}$ decreases until reaching $0.83 \pm 0.015 \mathrm{~V}$ on day 28 . The substrate that 
consistently reported lower $V_{p}$ was orange, only reaching values under $0.95 \pm 0.019$ volts as of the seventh day. Substrate voltage variations may be influenced by the development of microorganisms in the MFC since the substrates used may or may not degrade easily, which affects microorganism growth (Logroño et al., 2015; Khan and Obaid, 2015; Zhuang et al., 2012)

Fig. 2 (b) denotes average current $\left(C_{p}\right)$ generation. Orange generates $3.5 \pm 0.15 \mathrm{~mA}$ on the first day but drops rapidly on the second day to under $2 \pm 0.10 \mathrm{~mA}$. On the other hand, tangerine reports lower generation of electric current with values under $0.20 \pm 0.09 \mathrm{~mA}$ on day 28. Still, the lime MFC maintains $C_{p}$ values ranging from $2.2 \pm 0.14$ to $0.5 \pm 0.08 \mathrm{~mA}$ as of day 1 and until the last day of monitoring. The constant decrease in $\mathrm{C}_{\mathrm{p}}$ can be explained by the fact that waste microbes feed from the substrates available; however, as soon as the fresh substrate is depleted, the microbes start to die, thus causing a downward trend in current generation (Kamau, 2018). In addition, the higher generation of $\mathrm{C}_{\mathrm{p}}$ in the first few days can also indicate the presence of soluble compounds, which were initially oxidized and consumed progressively, forming an electrochemically active biofilm (Cercado et al., 2010). Also, the fruits used are known for containing vitamin C, which has antioxidant and reducing properties; which would generate a flow of electrons in the cell and produce the electricity (Vilaplana, 2007).

Fig. 2. Monitoring the generation of (a) voltage and (b) current in microbial fuel cells (MCFs) over 28 days
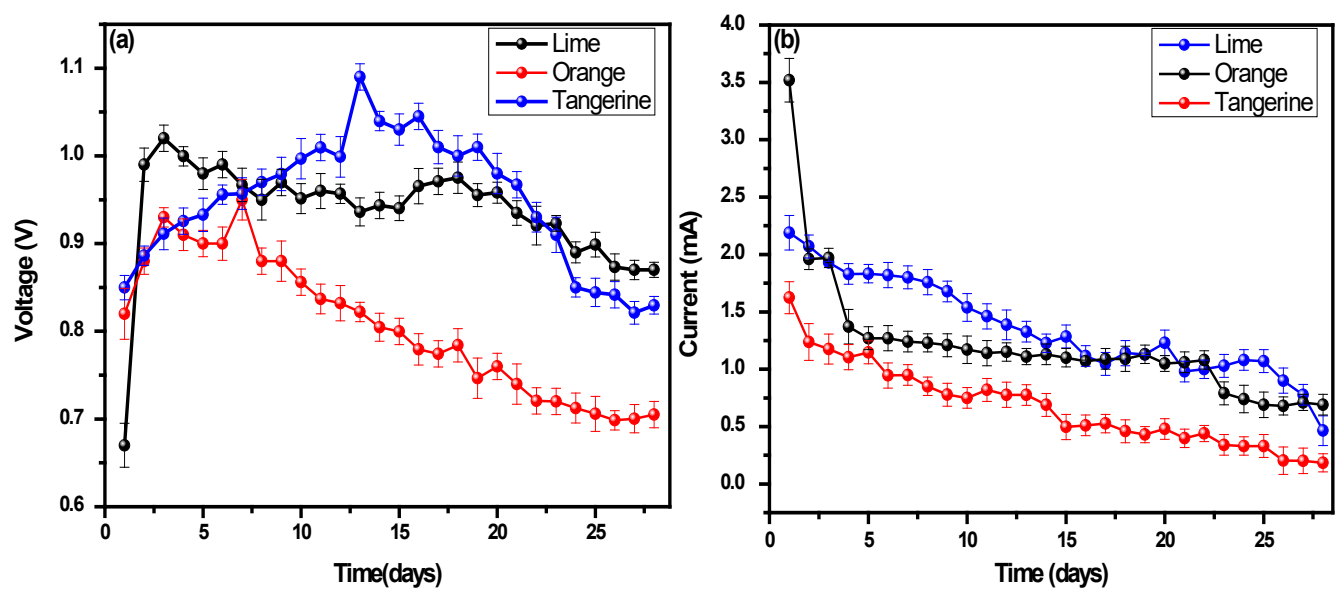

As depicted in Fig. 3, some volume variations may be observed for the MFC during the 28 days, wherein the orange MFC loses the most volume, in agreement with the voltages reported in Fig. 2 (a), because lower volumes generate lower voltages. On the other hand, the tangerine and lime MFCs generated the highest voltages because they lost the least volume during the monitoring period, which indicates a direct proportional relationship between degraded substrate volumes and voltage generation (Rabaey et al., 2004). However, Lyon et al. (2012) report that the influence of this parameter is small compared with the changes in the microbial community
Fig. 3. Microbial fuel cell (MFC) volume changes over 28 days

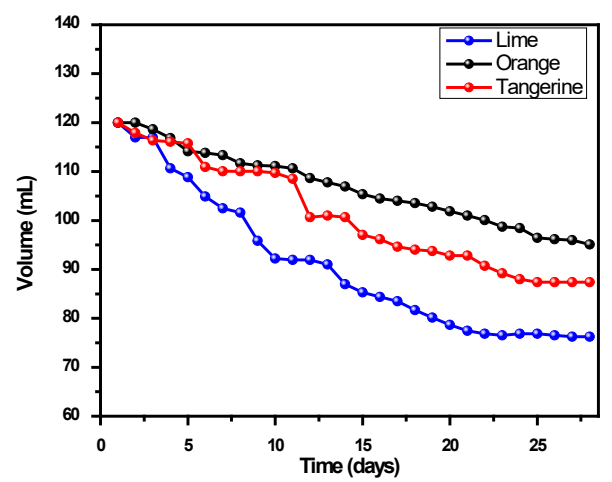


Fig. 4 (a) denotes pH values, wherein values increased on the first day of monitoring for three substrates. In fact, tangerine, lime, and orange increased from 4.4, 4.24 , and 4.51 on the first day to $6.25,6.98$, and 5.65 on the last day, respectively. Acidic $\mathrm{pH}$ values such as those reported by the fruit waste in the final days of the experiment are consistent with current generation since acidic conditions mean that carbon sources were consumed faster. Raghavulu et al. (2009) observed that the transfer of extracellular electrons ( $\mathrm{e}^{-}$) is more efficient in an acidophilic microenvironment than in a neutral environment. Hence, the increase in electron transfers triggers the oxidation process and, therefore, the cycles of electricity generation will become shorter.
Fig. 4 (b) depicts conductivity for the three substrates. Herein, considerable generation of electricity is reported from day 11 to 17 , with values exceeding 10 $\mathrm{mS} / \mathrm{cm}$ for tangerine, while peak values did not exceed $7 \mathrm{mS} / \mathrm{cm}$ for orange. In these cases, conductivity variations are caused by dissolved ions that contribute to electrons and degrade substrate resistance (Karthikeyan et al., 2016). As the conductivity values started to increase for these substrates, current values did not increase. Consequently, the limiting electricity generation can be attributed to other factors. For example, reduced mass transfers from electron donor may be significant, as well as slow proton flow rates hindering production (Malvankar et al., 2012).

Fig. 4. Microbial fuel cell (MFC) (a) pH and (b) conductivity over a period of 28 days

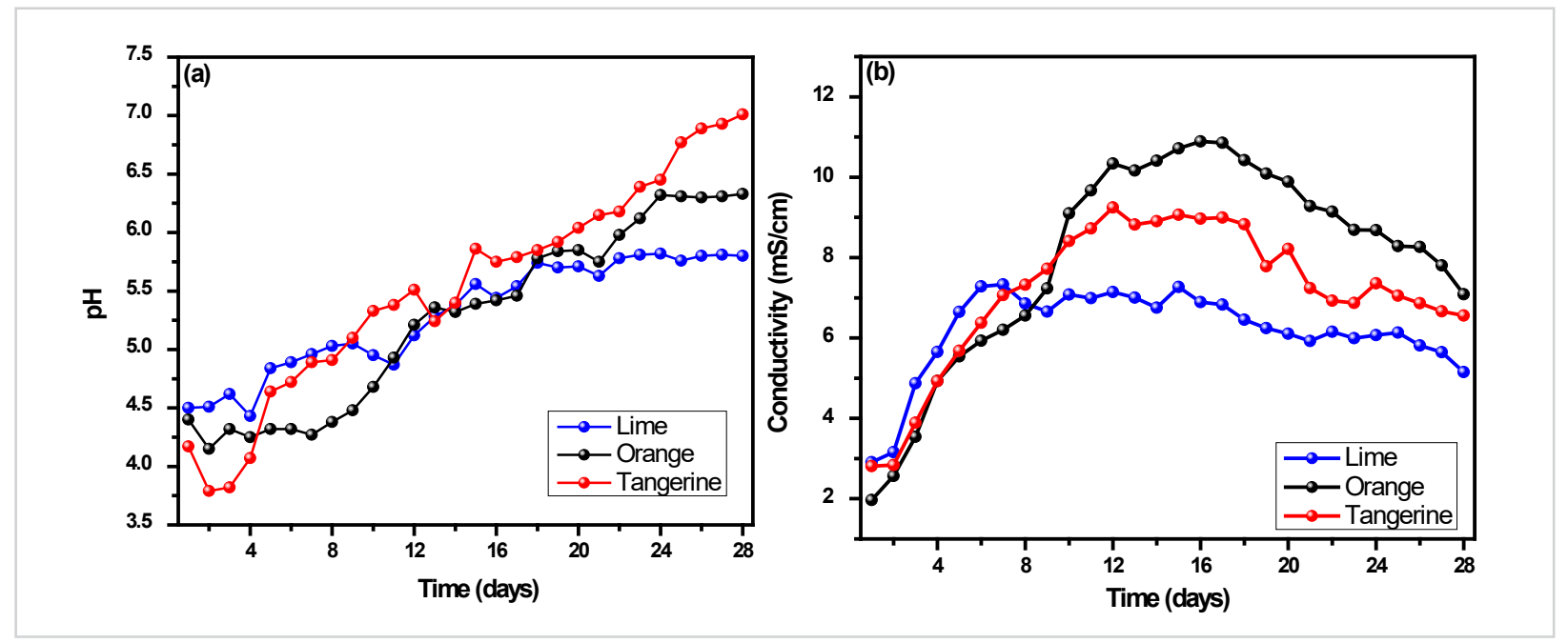

MFC polarization values for the three different substrates are shown in Fig. 5. These values were calculated using the polarization curve to characterize current as a function of voltage (Cheng and Logan, 2011; Mohan et al., 2008). Current values were measured directly using the resistors described in the Materials and Methods section (Deepika et al., 2015). When using orange as a substrate, the system was able to generate a PD of $0.0625 \pm 0.002 \mathrm{~W} / \mathrm{cm}^{2}$ at $0.049 \mathrm{~A} /$ $\mathrm{cm}^{2}$ of $\mathrm{CD}$ and a maximum of $0.94 \pm 0.011 \mathrm{~V}$. Meanwhile, the lime substrate generated a maximum $P D$ of $0.066 \pm 0.0012 \mathrm{~W} / \mathrm{cm}^{2}$ at $0.047 \mathrm{~A} / \mathrm{cm}^{2}$ of $C D$ and $a$ maximum voltage of $0.96 \pm 0.11 \mathrm{~V}$. Finally, the tangerine substrate reported $0.072 \pm 0.0014 \mathrm{~W} / \mathrm{cm}^{2}$ at $9 \times 10^{-4}$ $\mathrm{A} / \mathrm{cm}^{2}$ of $\mathrm{CD}$ and a maximum voltage of $1.06 \pm 0.18 \mathrm{~V}$. The power generated by this system slightly exceeds previous works not using a mediator, as shown in Table 1. In some cases, the system exceeds the voltage, $C D$, and power values reported in the literature, which mostly use wastewater and fruit and vegetable waste as substrates.

The corrosive nature of the metal electrodes used ( $\mathrm{Zn}$ and $\mathrm{Cu}$ ) did not affect their excellent production rates during the monitoring period. Dunas et al. reported 
Table 1. Performance of the microbial fuel cells (MFCs) against the literature

\begin{tabular}{|c|c|c|c|c|c|}
\hline Substrate type & MCF & $\begin{array}{l}\text { Maximum } \\
\text { voltage }(\mathrm{V})\end{array}$ & $\begin{array}{l}\text { Power density (PD) } \\
\qquad\left(\mathrm{mW} / \mathrm{m}^{2}\right)\end{array}$ & $\begin{array}{l}\text { Current density } \\
\text { (CD) }\left(\mathrm{mA} / \mathrm{cm}^{2}\right)\end{array}$ & Reference \\
\hline Sewage sludge & Double chamber & 0.66 & 59 & 175 & (Madhavan et al., 2016) \\
\hline Wastewater & $\begin{array}{l}\text { Double } \\
\text { cylindrical } \\
\text { chamber }\end{array}$ & 0.03 & 1.2 & 0.043 & (Wang et al., 2016) \\
\hline $\begin{array}{l}\text { Orange peel } \\
\text { waste }\end{array}$ & Double chamber & 0.59 & 358.8 & 847 & (Miran et al., 2016) \\
\hline Kitchen waste & Single chamber & 0.620 & 60 & -- & (Moqsud et al., 2014) \\
\hline $\begin{array}{l}\text { Plant waste } \\
\text { extract }\end{array}$ & $\begin{array}{l}\text { U-shaped } \\
\text { chamber }\end{array}$ & 0.5413 & 88,990 & 314.4 & (Javed et al., 2017) \\
\hline Food waste & Double chamber & 0.260 & 19,151 & 195 & (Hou et al., 2016) \\
\hline $\begin{array}{l}\text { Wastewater } \\
\text { from vegetable } \\
\text { oil industries }\end{array}$ & Double chamber & 0.563 & 1,260 & -- & (Firdous et al., 2018) \\
\hline Food waste & Double chamber & 0.046 & 29.6 & 88 & $\begin{array}{c}\text { (Chatzikonstantinou et al., } \\
\text { 2018) }\end{array}$ \\
\hline $\begin{array}{l}\text { Potato, tomato, } \\
\text { and lettuce } \\
\text { waste }\end{array}$ & Double chamber & 0.200 & 3.5 & 100.2 & (Du et al., 2015 ) \\
\hline $\begin{array}{l}\text { Fermentable } \\
\text { household waste } \\
\text { extract }\end{array}$ & Single chamber & 0.482 & 3.14 & 14 & (Tremouli et al., 2019) \\
\hline
\end{tabular}

the corrosion of the copper electrodes of their MFCs. Still, this may be due to the high saline content to which their electrodes were exposed, which accounts for reporting lower PD values than the ones reported in this research (Dumas et al., 2007). On the other hand, Nurettin reports that zinc electrodes in an MFC using organic matter as substrate generate a biofilm, rust, and corrosion, thus evidencing the electrochemical reaction of Zn (Nurettin, 2017)

The micrographs for the $\mathrm{Cu}$ and $\mathrm{Zn}$ electrodes after 28 days are shown in Fig. 6. As it can be observed, the $\mathrm{Cu}$ anode (Fig. 6 (a)) evidences a cracked layer, which may be due to corrosion or because of a biolayer formed by the oxidation of microorganism activity in the production and transfer of electrons (Rojas et al., 2020). This transfer takes place after forming the biolayer (Wang et al., 2012) although not all microorganisms attach to the anode since the upper layers of these microorganisms are connected to each other by endogenous electron transporters known as nanowires (Zhang et al., 2012; Rabaey et al. 2004).
Fig. 6 (b) denotes the zinc electrode (cathode), in which lower adhesion of the biolayer is observed. This may be due to the fact that the cathode receives and does not generate electrons (Tamakloe et al., 2015), and the thickness variations may be due to the reduction of the material but not due to oxidation (Meignanalakshmi and Kumar, 2016) or failures in the manufacture of the electrical circuit (Gokul et al., 2019). The pure microorganism cultures obtained on day 28 yielded gram-positive bacilli identified as Brevibaciullus laterosporus by the VITEK-2 system, as well as Candida boidini, as identified by the API 20C AUX system. Finally, the three MFCs with the highest voltage generation were selected and connected in series, generating 2.87 volts on the last day of monitoring and managing to switch on a green LED, as shown in Fig. 7. This fuel production provides a new way of leveraging waste from these three fruits as substrates (fuel). Hence, the companies that export and import these agricultural products may now reuse their damaged products (not suitable for consumption) and economically generate their own electricity. 
Fig. 5. Power and current density (PD and CD) from microbial fuel cells (MFCs) using (a) orange, (b) lime and (c) tangerine
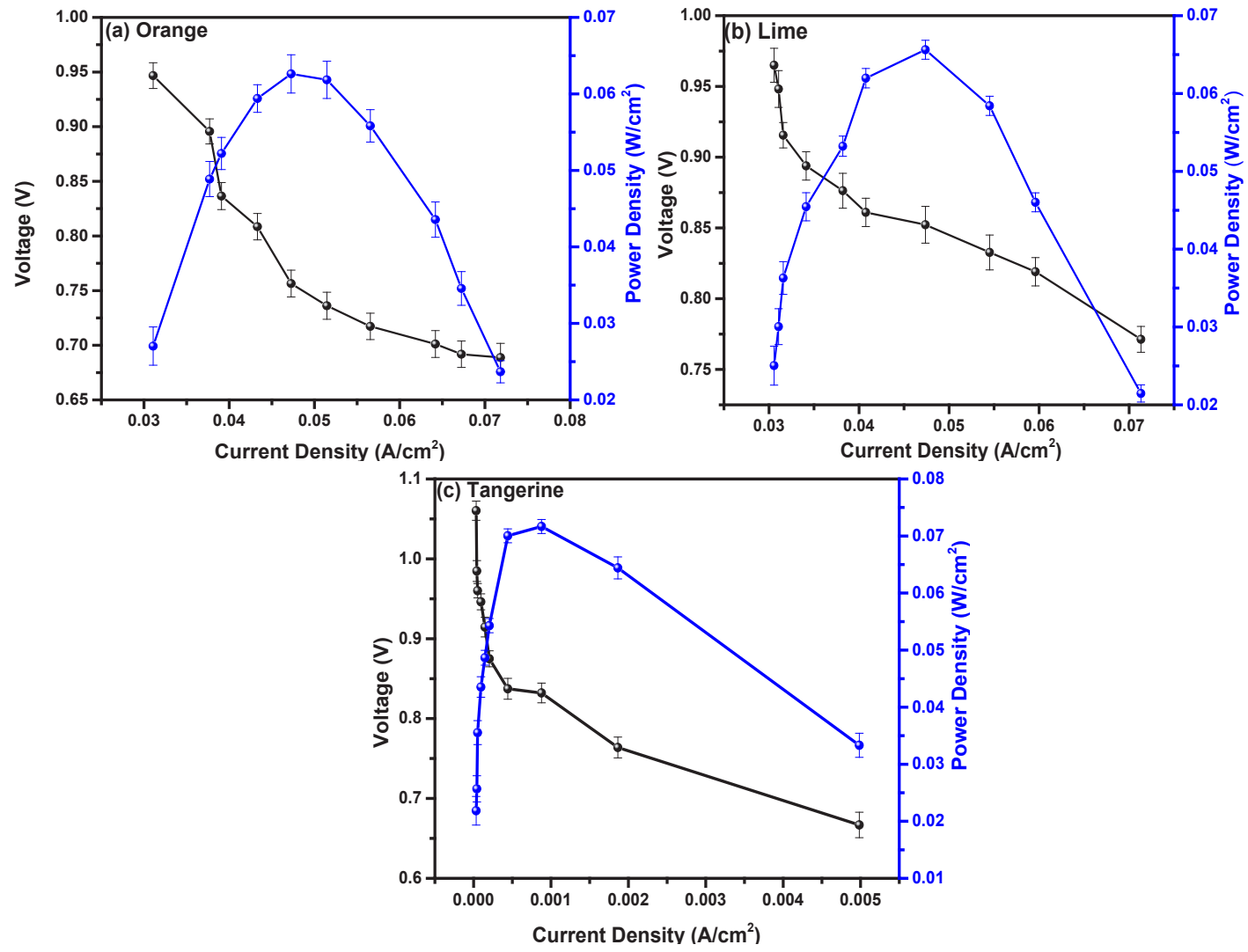

Fig. 6. SEM micrographs of the (a) anode and (b) cathode electrodes of the MFC

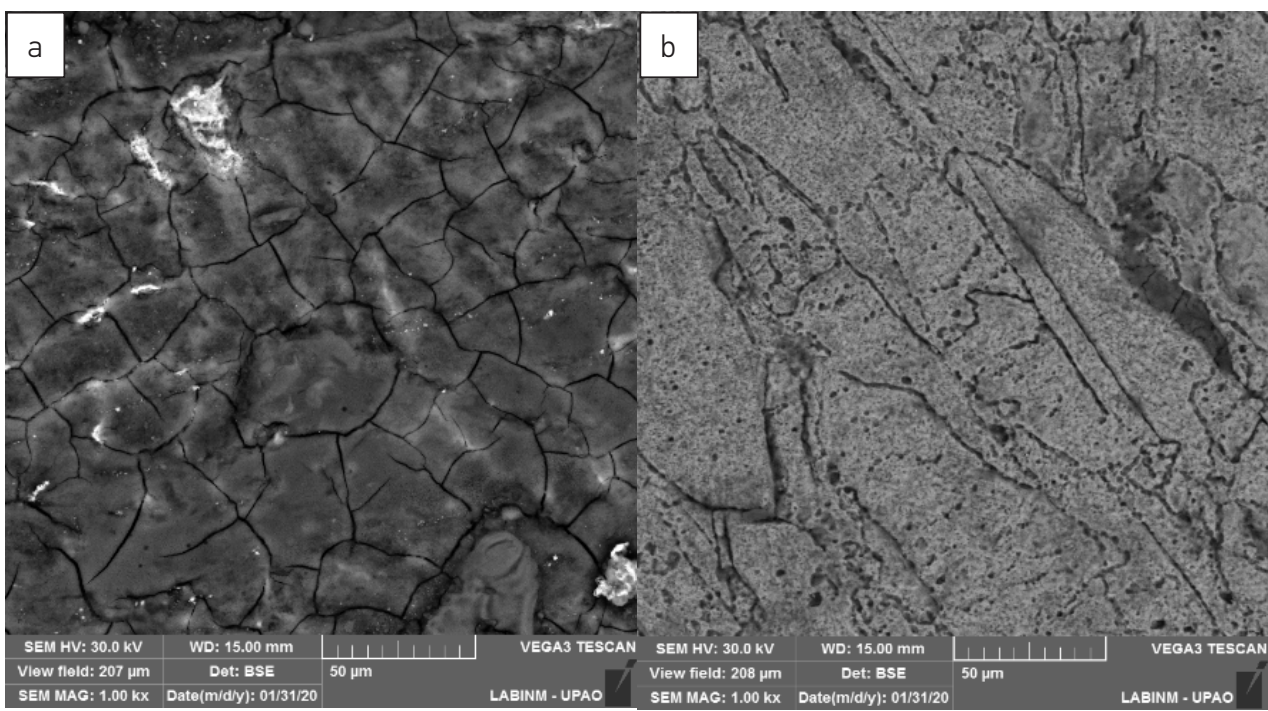


Fig. 7. Bioelectricity generation from agricultural waste

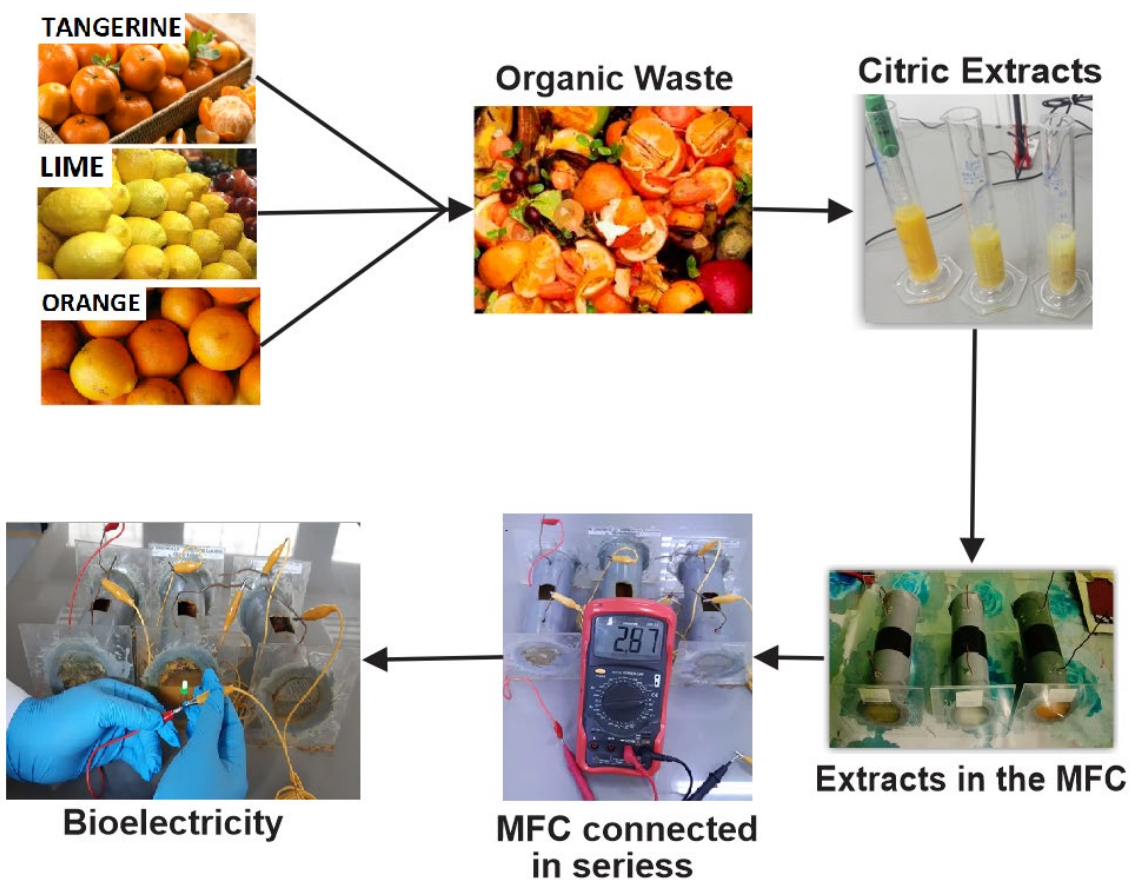

\section{Conclusions}

This research demonstrates that lime, orange, and tangerine waste can be repurposed to generate electricity through affordable MFCs using alternative zinc and copper electrodes instead of the conventional coal, graphite, and graphene electrodes. The research proved that tangerine and orange waste may generate maximum voltages of 1.06 and 0.95 volts, respectively, and the substrate volume and $\mathrm{pH}$ values are directly linked to current and voltage generation by the MFCs. The maximum PD generated was $0.072 \pm 0.0014 \mathrm{~W} / \mathrm{cm}^{2}$ at a CD of $9 \times 10^{-4} \mathrm{~A} / \mathrm{cm}^{2}$ in the tangerine MFC and the lowest PD generation was reported by the orange MFC with $0.0625 \pm 0.002 \mathrm{~W} / \mathrm{cm}^{2}$ at $C D$ of $0.049 \mathrm{~A} / \mathrm{cm}^{2}$. In addition, the Brevibaciullus laterosporus and Candida boidini microorganisms were identified. The research not only provides a new electricity generation alternative for fruit distribution centers, but also for companies that export and import this fruit. This way, these companies may reduce their electricity consumption costs by leveraging the fruit products damaged during the storage process or when being shipped to other countries.

\{Gurauskiene, 2006, Eco-design methodology for electrical and electronic equipment industry\}

\section{Acknowledgements}

We would like to thank Laboratorio de Investigación Multidisciplinario de la UPAO, headed by Dr. Luis Angelats, for their facilities provided. 


\section{References}

Centeno Calderón, L. G., Quintana Díaz, A., and López Fuentes, F. L. (2019) Efecto de un consorcio microbiano en la eficacia del tratamiento de aguas residuales, Trujillo, Perú. Arnaldoa, 26(1), 433-446. https://doi.org/10.22497/arnaldoa.261.26123

Cercado-Quezada, B., Delia, M. L., and Bergel, A. (2010) Testing various food-industry wastes for electricity production in microbial fuel cell. Bioresource Technology, 101(8), 2748-2754. https://doi.org/10.1016/j.biortech.2009.11.076

Chatzikonstantinou, D., Tremouli, A., Papadopoulou, K., Kanellos, G., Lampropoulos, l., and Lyberatos, G. (2018) Bioelectricity production from fermentable household waste in a dual-chamber microbial fuel cell. Waste Management \& Research, 36(11), 1037-1042. https://doi.org/10.1177/0734242X18796935

Cheng, S., and Logan, B. E. (2011) High hydrogen production rate of microbial electrolysis cell (MEC) with reduced electrode spacing. Bioresource technology, 102(3), 3571-3574. https:// doi.org/10.1016/j.biortech.2010.10.025

Dahiya, S., Kumar, A. N., Sravan, J. S., Chatterjee, S., Sarkar, O., and Mohan, S. V. (2018) Food waste biorefinery: Sustainable strategy for circular bioeconomy. Bioresource technology, 248, 2-12. https://doi.org/10.1016/j.biortech.2017.07.176

Deepika, J., Meignanalakshmi, S., and Thilagaraj, R. W. (2015) The optimization of parameters for increased electricity production by a microbial fuel cell using rumen fluid. International journal of green energy, 12(4), 333-338. https://doi.org/10.108 0/15435075.2013.847838

Du, H., Li, F., and Feng, C. (2015) Comparison of the performance of microbial fuel cell for treatment of different vegetable liquids and potato solid with different sizes. 土木学会論文集 $G$ (環境), 71(7), III_379-III_387. https://doi.org/10.2208/jscejer.71.III_379

Dumas, C., Mollica, A., Féron, D., Basséguy, R., Etcheverry, L., and Bergel, A. (2007) Marine microbial fuel cell: use of stainless steel electrodes as anode and cathode materials. Electrochimica acta, 53(2), 468-473. https://doi.org/10.1016/j.electacta.2007.06.069

Firdous, S., Jin, W., Shahid, N., Bhatti, Z. A., Iqbal, A., Abbasi, U., and Ali, A. (2018) The performance of microbial fuel cells treating vegetable oil industrial wastewater. Environmental technology \& innovation, 10, 143-151. https://doi.org/10.1016/j. eti.2018.02.006

Gajda, I., Greenman, J., and leropoulos, I. A. (2018) Recent advancements in real-world microbial fuel cell applications. Current opinion in electrochemistry, 11, 78-83. https://doi. org/10.1016/j.coelec.2018.09.006

Gokul Chandrasekaran, Sakthivel Periyasamy, Karthikeyan P R, "Minimization of Test Time in System-on-Chip using Ar- tificial Intelligence based Test Scheduling Techniques", Neural Computing and Applications, Vol. 32, pp. 5303-5312, May 2020. https://doi.org/10.1007/s00521-019-04039-6

Gokul Chandrasekaran, Sakthivel Periyasamy, Karthikeyan P. R. (2019) 'Test scheduling for system on chip using modified firefly and modified ABC algorithms', SN Applied Sciences, Vol. 1, No. 9, pp. 1079, August 2019. https://doi.org/10.1007/ s42452-019-1116-x

Gokul Chandrasekaran, Vanchinathan Kumarasamy, Gnanavel Chinraj, (2019) "Test Scheduling of Core Based System-on-Chip Using Modified Ant Colony Optimization" Journal Européen des Systèmes Automatisés, Vol.52, No. 6, pp. 599-605, December 2019. https://doi.org/10.18280/jesa.520607

Hou, Q., Pei, H., Hu, W., Jiang, L., and Yu, Z. (2016) Mutual facilitations of food waste treatment, microbial fuel cell bioelectricity generation and Chlorella vulgaris lipid production. Bioresource technology, 203, 50-55. https://doi.org/10.1016/j. biortech.2015.12.049

Javed, M. M., Nisar, M. A., Muneer, B., and Ahmad, M. U. (2017) Production of bioelectricity from vegetable waste extract by designing a U-shaped microbial fuel cell. Pakistan Journal of Zoology, 49(2). https://doi.org/10.17582/journal. pjz/2017.49.2.711.716

Kamau, J. M. (2018) Characterization of Voltage from Food Market Waste: Microbial Fuel Cells. Int J Biotech \& Bioeng, 4, 3-37.

Karthikeyan, R., Selvam, A., Cheng, K. Y., and Wong, J. W. C. (2016) Influence of ionic conductivity in bioelectricity production from saline domestic sewage sludge in microbial fuel cells. Bioresource technology, 200, 845-852. https://doi. org/10.1016/j.biortech.2015.10.101

Khan, A. M., and Obaid, M. (2015) Comparative bioelectricity generation from waste citrus fruit using a galvanic cell, fuel cell and microbial fuel cell. Journal of Energy in Southern Africa, 26(3), 90-99. https://doi.org/10.17159/2413-3051/2015/ v26i3a2143

Kondaveeti, S., Mohanakrishna, G., Kumar, A., Lai, C., Lee, J. K., and Kalia, V. C. (2019) Exploitation of Citrus Peel Extract as a Feedstock for Power Generation in Microbial Fuel Cell (MFC). Indian journal of microbiology, 59(4), 476-481. https://doi. org/10.1007/s12088-019-00829-7

Lefebvre, O., Ha Nguyen, T. T., Al-Mamun, A., Chang, I. S., and $\mathrm{Ng}, \mathrm{H}$. Y. (2010) T-RFLP reveals high $\beta$-Proteobacteria diversity in microbial fuel cells enriched with domestic wastewater. Journal of applied microbiology, 109(3), 839-850. https://doi. org/10.1111/j.1365-2672.2010.04735.x 
Li, H., Tian, Y., Zuo, W., Zhang, J., Pan, X., Li, L., and Su, X. (2016) Electricity generation from food wastes and characteristics of organic matters in microbial fuel cell. Bioresource technology, 205, 104-110. https://doi.org/10.1016/j.biortech.2016.01.042

Logroño, W., Ramírez, G., Recalde, C., Echeverría, M., and Cunachi, A. (2015) Bioelectricity generation from vegetables and fruits wastes by using single chamber microbial fuel cells with high Andean soils. Energy Procedia, 75, 2009-2014. https://doi. org/10.1016/j.egypro.2015.07.259

Madhavan, A., Nandakumar, V., Shetty, K. S., and Nair, B. (2016, March) Optimization of microbial fuel cell (MFC) operated with waste water as substrate. In 2016 International Conference on Electrical, Electronics, and Optimization Techniques (ICEEOT) (pp. 4403-4406). IEEE. https://doi.org/10.1109/ICEEOT.2016.7755551

Malvankar, N. S., Tuominen, M. T., and Lovley, D. R. (2012) Biofilm conductivity is a decisive variable for high-current-density Geobacter sulfurreducens microbial fuel cells. Energy \& Environmental Science, 5(2), 5790-5797. https://doi.org/10.1039/c2ee03388g

Meignanalakshmi, S., and Kumar, S. V. (2016) Bioelectricity production by using goat (Capra hircus) rumen fluid from slaughterhouse waste in mediator-less microbial fuel cells. Energy Sources, Part A: Recovery, Utilization, and Environmental Effects, 38(10), 1364-1369. https://doi.org/10.1080/15567036.2014.907846

Miran, W., Nawaz, M., Jang, J., \& Lee, D. S. (2016) Conversion of orange peel waste biomass to bioelectricity using a mediator-less microbial fuel cell. Science of the Total Environment, 547, 197-205. https://doi.org/10.1016/j.scitotenv.2016.01.004

Mohan, S. V., Raghavulu, S. V., and Sarma, P. N. (2008) Biochemical evaluation of bioelectricity production process from anaerobic wastewater treatment in a single chambered microbial fuel cell (MFC) employing glass wool membrane. Biosensors and Bioelectronics, 23(9), 1326-1332. https://doi.org/10.1016/j.bios.2007.11.016

Moqsud, M. A., Omine, K., Yasufuku, N., Bushra, Q. S., Hyodo, M., and Nakata, Y. (2014) Bioelectricity from kitchen and bamboo waste in a microbial fuel cell. Waste Management \& Research, 32(2), 124-130. https://doi.org/10.1177/0734242X13517160

Nurettin, Ç. E. K. Examination of Zinc Electrode Performance in Microbial Fuel Cells. Gazi University Journal of Science, 30(4), 395-402.

Rabaey, K., Boon, N., Siciliano, S. D., Verhaege, M., and Verstraete, W. (2004) Biofuel cells select for microbial consortia that self-mediate electron transfer. Appl. Environ. Microbiol., 70(9), 5373-5382. https://doi.org/10.1128/AEM.70.9.5373-5382.2004

Raghavulu, S. V., Mohan, S. V., Goud, R. K., and Sarma, P. N. (2009) Effect of anodic pH microenvironment on microbial fuel cell (MFC) performance in concurrence with aerated and ferricyanide catholytes. Electrochemistry Communications, 11 (2), 371-375. https://doi.org/10.1016/j.elecom.2008.11.038
Rahimnejad, M., Adhami, A., Darvari, S., Zirepour, A., and Oh, S. E. (2015) Microbial fuel cell as new technology for bioelectricity generation: a review. Alexandria Engineering Journal, 54(3), 745-756. https://doi.org/10.1016/j.aej.2015.03.031

Rojas Flores, S., Naveda, R. N., Paredes, E. A., Orbegoso, J. A., Céspedes, T. C., Salvatierra, A. R., and Rodríguez, M. S. (2020) Agricultural Wastes For Electricity Generation Using Microbial Fuel Cells. The Open Biotechnology Journal, 14(1). https://doi. org/10.2174/1874070702014010052

Shah, M. S., Chetan, N., Moses, V., Soumya, C., and Shobha, G. (2019) Power Generation from Kitchen and Industrial Waste Water using Microbial Fuel Cells (MFCs) with Graphite Cathode and Anode. Journal of Alternate Energy Sources and Technologies, 7(1), 14-22.

Sivaa, G. V., Prashanthia, R., and Mohanb, N. INTERNATIONAL JOURNAL OF ENGINEERING SCIENCES \& RESEARCH TECHNOLOGY BIO-ELECTRICITY PRODUCTION FROM ORGANIC WASTE USING SINGLE CHAMBER MICROBIAL FUEL CELL (MFC).

Slate, A. J., Whitehead, K. A., Brownson, D. A., and Banks, C. E. (2019) Microbial fuel cells: An overview of current technology. Renewable and sustainable energy reviews, 101, 60-81. https://doi.org/10.1016/j.rser.2018.09.044

Tamakloe, R. Y., Opoku-Donkor, T., Donkor, M. K. E., and Agamasu, H. (2015) Comparative study of double-chamber microbial fuel cells (DC-MFCs) using Mfensi clay as ion-exchange-partition: Effect of electrodes. African Journal of Science, Technology, Innovation and Development, 7(3), 207-210. https://doi.org/ 10.1080/20421338.2015.1043706

Toding, O. S. L., Virginia, C., and Suhartini, S. (2018, December) Conversion banana and orange peel waste into electricity using microbial fuel cell. In IOP Conference Series: Earth and Environmental Science (Vol. 209, No. 1, p. 012049). IOP Publishing. https://doi.org/10.1088/1755-1315/209/1/012049

Tremouli, A., Karydogiannis, I., Pandis, P. K., Papadopoulou, K., Argirusis, C., Stathopoulos, V. N., and Lyberatos, G. (2019) Bioelectricity production from fermentable household waste extract using a single chamber microbial fuel cell. Energy Procedia, 161, 2-9. https://doi.org/10.1016/j.egypro.2019.02.051

Victor, P. A. (2017) Pollution: economy and environment. Routledge. https://doi.org/10.4324/9781315108483

Vilaplana, M. O. N. T. S. E. (2007) Antioxidantes presentes en los alimentos. OFFARM, 26(10).

Wang, G., Zhang, L., and Zhang, J. (2012) A review of electrode materials for electrochemical supercapacitors. Chemical Society Reviews, 41(2), 797-828. https://doi.org/10.1039/C1CS15060J

Wang, J., Bi, F., Ngo, H. H., Guo, W., Jia, H., Zhang, H., and Zhang, X. (2016) Evaluation of energy-distribution of a hybrid microbial 
fuel cell-membrane bioreactor (MFC-MBR) for cost-effective wastewater treatment. Bioresource technology, 200, 420-425. https://doi.org/10.1016/j.biortech.2015.10.042

Xu, B., Lan, J. C., Sun, Q., Hsueh, C., and Chen, B. Y. (2019) Deciphering optimal biostimulation strategy of supplementing anthocyanin-abundant plant extracts for bioelectricity extraction in microbial fuel cells. Biotechnology for Biofuels, 12(1), 46. https://doi.org/10.1186/s13068-019-1385-z

Yu, Z., Leng, X., Zhao, S., Ji, J., Zhou, T., Khan, A., and Li, X. (2018) $A$ review on the applications of microbial electrolysis cells in an- aerobic digestion. Bioresource technology, 255, 340-348. https:// doi.org/10.1016/j.biortech.2018.02.003

Zhang, G., Zhao, Q., Jiao, Y., Wang, K., Lee, D. J., and Ren, N. (2012) Efficient electricity generation from sewage sludge usingbiocathode microbial fuel cell. Water research, 46(1), 43-52. https://doi.org/10.1016/j.watres.2011.10.036

Zhuang, L., Zheng, Y., Zhou, S., Yuan, Y., Yuan, H., and Chen, Y. (2012) Scalable microbial fuel cell (MFC) stack for continuous real wastewater treatment. Bioresource technology, 106, 8288. https://doi.org/10.1016/j.biortech.2011.11.019 